\title{
ATTRIBUTES AND DETERMINANTS OF AN AGRICULTURAL ENTERPRISE MANAGEMENT
}

\author{
Dagmara Bubel \\ Czestochowa University of Technology, Poland
}

\begin{abstract}
The aim of the paper is to analyse solutions connected with the complex nature of an enterprise and to attempt to identify the characteristics of a modern enterprise. An enterprise as the most important link in the chain of the national economy is a complex research unit. Due to variety of enterprises and uniqueness of managerial practices, management of an enterprise is analysed and described by numerous scientific disciplines.
\end{abstract}

Keywords: management of an enterprise, agricultural enterprises, management of agricultural holdings

DOI: $10.17512 /$ znpcz.2016.1.06

\section{Introduction}

The economic changes taking place throughout the decade of the 1990s and the first decade of the 21 st century brought a lot of changes in the perception of enterprises as economic entities. Among the most important issues connected with the new way of perceiving enterprises is distinction between study of an enterprise and business economics. While the latter deals with the production process and assesses it from the economic point of view, stressing the issues of revenue, cost, income or profit from the individual activities and the whole entity, the former treats them as the subject of investments and production, i.e. it examines the issue of the functioning of enterprises in a broader sense. Business economics is very useful in the process of management, as it provides the necessary knowledge about profitability of the different economic activities. It is hard to imagine a modern manager who does not link his/her decisions with economic balance. Business economics is highly useful: it focuses on determining the economic result of the different activities and the whole entity and provides the main support in the management process. Right managerial decisions are those that ensure a positive financial result that enables reproduction of the assets. Economics perceives an enterprise as an existing entity and does not examine sources of its financing, i.e. it does not treat an enterprise as an investment entity. In contrast, study of an enterprise not only deals with decision-making, but, more importantly, treats an enterprise as an investment entity. This approach makes it go beyond the conceptual framework in which business economics is interested, as study of an enterprise takes into account invested capital and expects a satisfactory rate of 
return, taking into account not only the cost of outside capital, but also that of equity. The cost of equity is equal to the value of lost profits, i.e. we can talk in this case about an alternative cost. Therefore, not every level of profit is satisfactory for the owner of capital. The minimum of satisfaction is such a level of operating profit that after taxation will be at least equal to the weighted cost of equity and outside capital. The formula that presents an enterprise's economic results in this way is economic added value (Czyżewski, Kryszak 2015, pp. 21-32).

The aim of the paper is to present and diagnose certain changes occurring in management of agricultural enterprises. Through analysis of the attributes and determinants characterising modern enterprises, the paper highlights the process of blurring of differences between agricultural enterprises and enterprises from other industries in terms of applied methods and instruments of management. The discussion on the complexity of processes in enterprises was based on findings of German researchers' works.

\section{The position and value of a modern agricultural enterprise}

Analysis of modern enterprises shows the emphasis of the leading role of an enterprise's owner who invests equity and expects profits from its increase. Therefore, the owner is directly interested in the current and perspective effectiveness of the functioning of the enterprise. He/she is not interested in activity aimed at production at any cost, does not agree to maintain assets that are not directly connected with production activity, does not tolerate bureaucracy, generation of too many posts outside production or excess staff. The principles of the functioning of enterprises in a centrally controlled economy and lack of the capital market created a unilateral and simplified way of perceiving the value of an enterprise.

The value of an enterprise was equated only with the value of the real capital in the form of assets, while ignoring the value that shows the dynamic aspect of capital, which is connected with the process of multiplying its value. The rules of the functioning of the market economy lead to enterprises being assessed mainly in terms of their ability to generate revenue. Apart from assets, many other elements serve this purpose, connected, among other things, with proper structure of an organisation, production structure, proper management, professionalism of the staff and many non-production factors that create the so-called value of reputation. Because of that, the value of an enterprise may significantly differ from the value of its material assets. Thus, if we view the problem retrospectively, we can say that the book value has been replaced by the market value. This necessitates departure from the previous indicators of an enterprise assessment that focused on analysis referring to the past. This is characteristic of all accounting indicators connected with balance sheet and outturn account. They reflect, in a static and short-term way, the past rather than what is the most important thing from the perspective of a company's owner, i.e. the future value and expected rate of return from the capital invested. Another characteristic of modern agricultural enterprises is decreased number of employees compared with the level of staffing from the second half of the 20th century. There 
has been an increase in the level of employees' education and possibilities of working at multiple posts. The increase in the education level of employees corresponds to the level of technical equipment. Modern, efficient machines are not only expensive, but also their operation is technically complicated, therefore they require extensive technical knowledge. We can also observe changes in employees' mentality - they identify themselves with their place of work, being aware that job safety requires showing care about the place of work. The employees are not longer divided into those who produce and those who deal with sales. Nowadays, all employees are interested not only in production but also sales, which is connected with manufacture of products with high qualitative parameters. There is a quite large group of farms that represent production level comparable with leading European entities in all parameters. It should be added that high production is connected with high profitability in such entities. This debunks the myth of unprofitable production when its level significantly exceeds the average one.

In large-scale agriculture we can observe a change in the organisational form. In the traditional approach, the owner of the property was at the same time the manager. In today's conditions, there are two fundamental options describing separation of the ownership of the property from its management. One is connected with an investor who invests his/her capital in agricultural assets, while the other option involves a number of smaller investors whose capital forms the assets of an enterprise. In both cases, there is departure from the traditional model of a private enterprise - this new organisational and legal form is regarded as the biggest departure in the theory of enterprises' behaviour.

Consequences of this phenomenon are visible both in the emergence of new types of the ownership of enterprises and the necessity to revise the existing views on the formulation and definition of the objectives of their activity (Jaki 2012, pp. 115-119).

Separating the function of ownership from management was in the first place connected with the process of capital concentration, which required that an enterprise obtained necessary financial resources directly on the market - from investors, who often remained anonymous. The employment of capital from a wide and numerous group of anonymous co-owners in the activity of enterprises leads, on the one hand, to dispersal of ownership among many stakeholders, while on the other hand, to demand for management specialists who are responsible for managing increasing enterprises. In this way, the once common capitalism of entrepreneurs has changed into managerial capitalism. A further consequence of this state of affairs is the fact that a hired manager running an enterprise of anonymous and dispersed owners has become a very important, and sometimes the only decision-maker in matters concerning operational management of an enterprise. He/she acquired not the right to a thing or the right to profits, but he/she actually acquired the economic ownership title. This phenomenon leads to emergence of managerial capitalism in agriculture ( Haipeter 2016, pp. 11-43).

However, nobody understands the enterprise so well, nobody is ready to devote his/her own income for the benefit of the company, and nobody links his/her fate with the enterprise so strongly as the owner. Only the owner thinks about the 
future, resigns from current consumption, denying himself/herself profits today so that the next generations could gain competitive advantage. Therefore, professional managers should also be connected with the enterprise they manage through property.

Management of an enterprise by a manager does not decrease the owners' pressure on increased effectiveness of the capital employed, especially the equity. Therefore, institutional owners strive to guarantee the achievement of their objectives, including the main objective, i.e. seeking to maximise the market value of an enterprise. This requires the use of effective management instruments and supervision of enterprises, which has been presented in figure 1 .

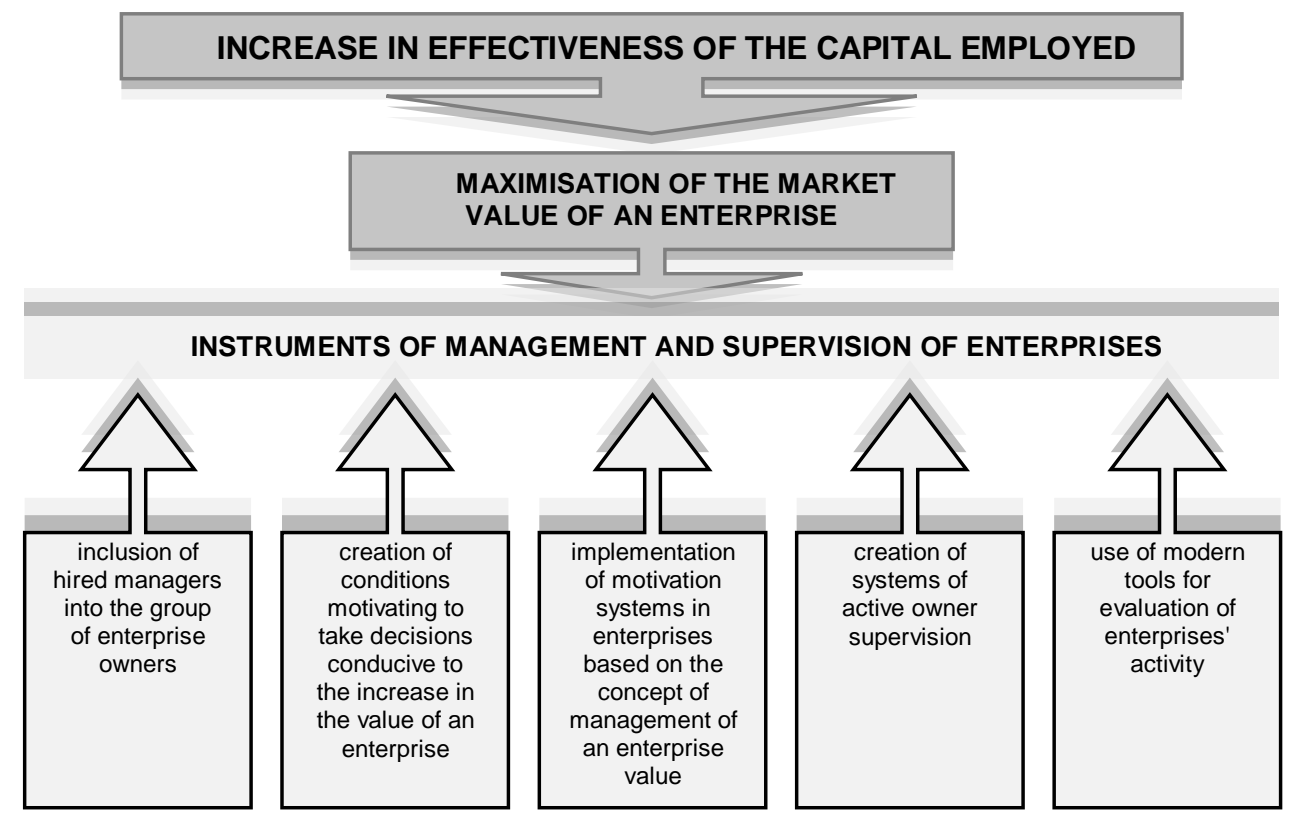

Figure 1. Instruments of management and supervision of enterprises

Source: Own study based on: Burmann 2013, pp. 34-37.

Looking at agricultural enterprises analytically, one can notice that they use an appropriate organisational structure, as they prefer flat structures with a small number of intermediate levels between the decision-making body and implementing body. In Polish agricultural enterprises, the process of labour substitution is at a more advanced level than in agricultural enterprises in France, England, Germany or other countries, although labour costs are relatively low. Despite low profitability of agriculture, agricultural enterprises are successful in ensuring production profitability and financing economic activity. We no longer act according to the model in which all available resources are consumed in the period of prosperity, and when the economic situation in agriculture gets worse it means a period of risk. Today's farmers-entrepreneurs are very prudent in gathering and allocating means of 
payment. Maintaining financial reserves is nowadays an almost common practice. The approach to the problem of investing in fixed property differs, but it does not result from lack of knowledge of the problem, but from different situations connected with the form of possession. While owners of fixed property can plan their activity prospectively, taking into account plans of long-term development, entrepreneursleaseholders are in a much more complicated situation. Unsuccessful attempts to solve the problem of reprivatisation are a serious setback in rational long-term planning. This is because planning is an important element of running a company in a wise manner.

Operational management, designed to control an enterprise on a continuous basis, is not sufficient especially in agriculture, where the quality and distribution of soils are constant, and possession of livestock buildings determines livestock raising and makes prediction of the future an important element of rational management.

Due to their distinguishing features, agricultural enterprises are a separately treated group of economic entities, although this separateness is nowadays significantly diminished. Fundamental differences occur at environmental and technical levels, while in terms of management principles the similarity is large. This similarity can be clearly seen in the reaction to the present crisis. Studies were conducted (Wulf 2013; Kleinhanß 2015), to find out the reactions of agricultural enterprises to the crisis and compare them with corresponding behaviour of industrial enterprises.

\section{Analysis of the study results}

Crisis is not a phenomenon that has been repeatedly described in economic literature. In 2014 (Domańska, Serwa 2013, pp. 3-19), conducted studies analysing the impact of world economic crisis on the functioning of agricultural enterprises in Europe. Summing up the findings of the studies, it can be said that one of the more important signs of the crisis was decrease in prices of agricultural crops, which affected all enterprises, with only pig farmers registering the increase in the demand. There was an increase in prices on the market of products for agricultural production. As a result of the decreased demand for agricultural products, companies purchasing these products had problems with settling current liabilities, which led to increasing payment gridlock. In $45 \%$ of the enterprises surveyed, it was necessary to collect the money due. Despite the above-mentioned difficulties, an overwhelming majority of enterprises did not consider cutting employment. The reason for that could have also been the fact that the employment in the enterprises surveyed was low - 4.09 full-time employees per 100 ha UAA (Domańska, Serwa 2013, pp. 3-19). There were also no intentions to reduce employees' remuneration. The crisis affected in particular the area of investments in fixed assets. Over $75 \%$ of enterprises decided to reduce investments, although, at the same time, $27 \%$ of enterprises declared increase in investments, trying to take advantage of favourable prices of building materials and relatively low prices of construction works (Feist, Fuchs 2013, pp. 197-209). Interestingly, enterprises did not intend to reduce the level of intensity. 
Access to capital is of fundamental importance for the functioning of enterprises. Surveys show that $42 \%$ of enterprises had a more difficult access to short- and long-term capital. Banks' problems during a crisis and unwillingness to grant credits lead to the privileged position of the equity. This results in decrease in investments and decrease in investment demand, and consequently reduction of employment (Kozak 2013, p. 224-230).

It should be also stressed that during the crisis agricultural managers showed a good knowledge, ability to cope in difficult conditions, high managerial intuition, ability to consolidate the staff and ability to control costs. The surveys showed that most enterprises wanted to wait out, concentrating on limiting the consequences of the crisis and waiting for economic recovery.

The farmers surveyed did not take significant investment measures, did not consider organisational changes, better adjustment of the production structure to the market needs, wider use of the key success factors, etc. A small group of enterprises that were in a good economic situation when the crisis hit, considered whether activation made sense.

In Poland, the crisis was not as severe as in other EU countries. Economists agree that it was caused by a slight decrease in spending on investments and consumption, Polish currency weakening and limited linkage between the Polish and international economies.

Just as the crisis in Poland wasn't as severe as in other countries, its extent in agriculture in the Polish economy was smaller. The typical signs of crisis in agriculture include a decrease in prices and sales due to a significantly reduced demand. There was also a decrease in the number of yield-forming factors used in farms. The above-mentioned effects of a crisis do not pose a significant threat to further development of agriculture.

The uniqueness of the crisis situation poses a lot of questions and makes one wonder whether science sufficiently knows the symptoms of crisis; whether it can formulate appropriate ways of dealing with crisis; whether it can indicate managerial recommendations to minimise the effects of crisis; whether crisis is democratic, i.e. it equally affects all the entities; whether small enterprises take advantage of the rubber effect and large ones are stable; whether crisis triggers entrepreneurship or causes uncertainty, apathy, discouragement, or rather it sparks new initiatives, is a stimulus for new strategies or even a breakthrough in management.

\section{Sinecure of management in agricultural enterprises}

A thorough analysis of behaviour of enterprises shows significant weaknesses in their management. With respect to all enterprises, not only agricultural ones, it is justified to say that their management is based too much on intuition rather than on a professional analysis, managers have insufficient analytical basis to use it for taking authorised managerial decisions, and costs of production activity are evaluated intuitively instead of a professional analysis of costs. It should also be stressed that there are no organisational audits, there is little discussion about 
models as desired organisational structures, and monitoring of changes should be replaced by planning of costs and analysis of the production structure. The budget method can by all means be also used in management of agricultural enterprises. Often, what is intuitively evaluated as the best functioning part of an enterprise turns out to be the worst after a professional analysis is implemented. Introduction of full settlement of costs in an enterprise leads in many cases to reduction of investment purchases, and even results in the sale of part of the property.

Agricultural enterprises are integrally connected with the picture of rural areas and are actively shaping it. The impact of large-scale farms on the life of rural areas has always been visible and is still significant. Such farms have always been centres of the agricultural culture: both in the area of agro-technics and animal breeding. They have always been promoters, often the most effective ones. It is therefore no accident that the leading plant and animal breeding centres are situated in large estates. However, there is a growing number of smaller farms with significant achievements in the area of breeding progress. It should be added that both in non-agricultural activity and in agriculture, we can clearly notice benefits of the economics of scale ( Wigier 2013, pp. 22-41). Because of this fact, large entities can to a larger extent use the benefits of the progress. There is greater use of labour resources and means of production, therefore production means wear out faster and are replaced by newer work tools more frequently. This is very important, as the more specialist the equipment, the more expensive it is, and the narrower the labour resources. The progress in modernising means of production is faster in the area of technologically advanced equipment than less complex solutions. This explains why the latest generation technical solutions are encountered in large enterprises. We can talk here about circles of impact - farms located closer to large estates can constantly watch introduced changes and successively monitor their effects.

The picture of agricultural enterprises will be affected in the future by the concept of sustainable development of agriculture, implemented and propagated as part of common agricultural policy. It assumes that agricultural holdings harmoniously and simultaneously fulfil three functions: agricultural-environmental, economic and social (Matysiak, Struś 2015, pp. 11-21). According to these assumptions, sustainable agriculture means systematic and permanent development as well as an increased level of production that enables increased profit, modernisation of technical equipment, increase in work efficiency and security as well as in social security, while fulfilling certain social and ecological expectations (Home, Jawtusch, Moschitz 2015, pp. 33-58).

In the economic practice, this means introduction of production technologies that are socially accepted, economically justified and environmentally admissible. Such approach to the issue of sustainable development seems particularly justified in the case of large-scale farms, i.e. large entities that attach great importance to competitiveness (Kagan 2015, pp. 78-94). Such enterprises use the so-called economies of production scale or apply simplifications in farming, therefore they are not predisposed for organic farming. However, they still are able, especially when using the latest technical and technological solutions, i.e. the so-called 
precision farming (Wójcicki, Rudeńska 2015, pp. 5-15), to meet the minimum requirements of environmental protection, not to mention meeting certain social expectations, such as ensuring food safety or high quality of offered products. This is all the more so since there is an increasingly widespread view among economists that sustainable development should be understood and perceived as aiming for achieving the state of balance rather the state itself. Achievement of the state of balance seems difficult due to the variety of the factors and the fact that this situation does not carry any element of development in it.

The approach to balance in agricultural holdings is also evolving, which can be confirmed by the fact that in the market economy, in order to achieve balance between the most important balance sheets in an agricultural holding, the participation of external inputs is allowed. In this context, introduction of numerous new solutions in the area of agricultural ecosystem does not have to lead to the inevitable clash between the imperative of ecology or sociology and the imperatives of economy. The proof confirming this hypothesis is the introduction of modern methods of logistics management ( Brzozowska 2013, pp. 44-54) in agricultural enterprises, among other things, which contribute to a visible reduction of costs and increase in the effectiveness of a company. In order to meet certain social expectations, it may be helpful when agri-business enterprises introduce such concepts as: corporate social responsibility, ethical business, triple bottom line or stakeholder relation management.

It should be stated that it is very likely that adoption of a development strategy oriented towards modern agriculture, which is efficient in technical and economic terms and at the same time environmentally and human friendly, will cause many important changes to the image of agriculture and strengthen the position of large agricultural enterprises.

Processes of organisation, economics and management have no end, but they have their optimum in the static perspective, whereas in the dynamic perspective, i.e. under specific conditions and in real structures, they remain only an unavailable ideal. One should assume that future changes referring to agricultural enterprises will be similar to those observed in other sectors of the national economy. Continuous changes occur in the environment of enterprises, which has been presented in figure 2:

Due to the dynamic character of the functioning of an enterprise, the significance and importance of various management methods and techniques change. In the near future, agricultural enterprises should consider, to a greater extent than before, active participation in clusters whose development in Poland still lags behind foreign countries. Food clusters ( Figiel., Kuberska, Kufel 2014, pp. 23-27) have optimistic conditions of development, and agricultural enterprises and institutions operating in agriculture and for the benefit of agriculture will play a key role in the process of their development. Agricultural managers will probably be interested in alliances as a special form of cooperation based on mutual benefits. Perhaps some enterprises will choose heterarchy as the most appropriate form of cooperation that strengthens the market position (Winkler, 2016, pp. 85-102). Even today, many enterprises should use the method of lean 
management and develop it, as it brings measurable benefits in the process of production, warehouse management and employment. The aim of lean management is to make an enterprise leaner by introducing significant changes in the area of their activity, in the structure of a company's assets, way of organisation and in HR management. Lean management brings measurable benefits. Studies show that using this technique it is possible to reduce stocks, decrease storage area, increase work productivity and reduce production costs (Wiedemann 2015, pp. 215-226).

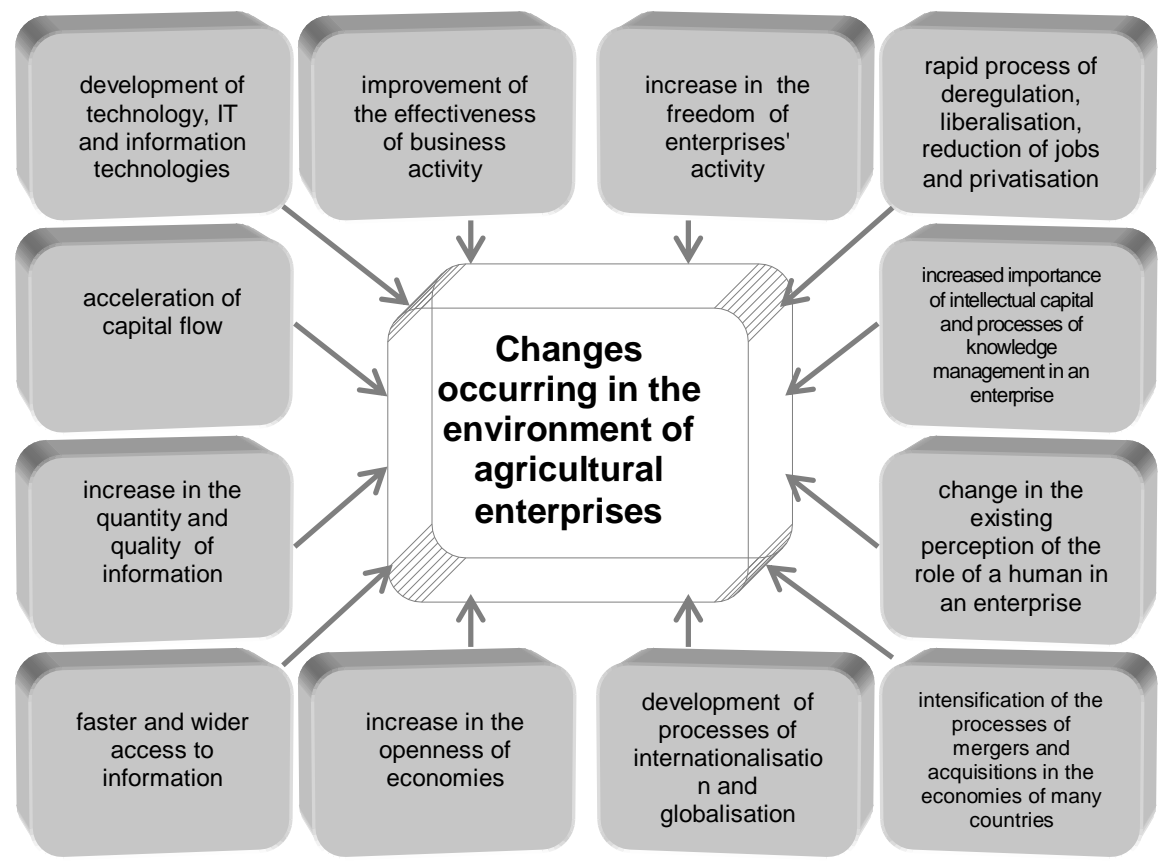

Figure 2. Changes occurring in the environment of agricultural enterprises

Source: Own study based on: Schäfer 2013, p. 222.

Seeking ways to improve their financial situation and build market advantage, some enterprises use the technique of benchmarking. Benchmarking consists in comparing processes and practices used by own enterprise with those used in enterprises regarded as the best in a specific field. The result of such an analysis serves as the basis for improving business processes. Benchmarking is not simply imitation, but it is about observing how others work and doing the same. It is about identifying factors that cause the analysed process to be performed effectively, and indicating similar possibilities in own enterprise. It is, however, necessary to warn against the temptation to automatically transfer someone else's solutions, even very good ones, as they may have been tested but in a different environment, different conditions that do not occur in a given enterprise. Therefore, benchmarking is about learning and creative adaptation of the best practices (Frank, Fischer, Voeste 2014, pp. 217-230). 
An important role in management of enterprises is played by outsourcing, which consists in using external resources, contracting out processes necessary for the functioning of own enterprise to specialised external entities which can perform them more effectively than in the own enterprise. This usually refers to auxiliary tasks that require appropriate qualifications, knowledge, equipment or possession of appropriate means of production. Today, the following services are very often outsourced: security, legal, IT and cleaning services, services connected with accountancy, transportation, warehousing, picking or distribution (Stabryła 2014, pp. 495-504). Evidence of changes is also the strengthening of the theory of stakeholders. A view is becoming established that the role and importance of an enterprise is not an interest of the enterprise alone. It is not only the owners of the property that are interested in the situation of an enterprise, but also numerous stakeholders: employees, customers, partners, lenders, the state, society and the media. Taking into account a wide range of stakeholders, four dimensions of the activity of an enterprise can be distinguished, as presented in figure 3.

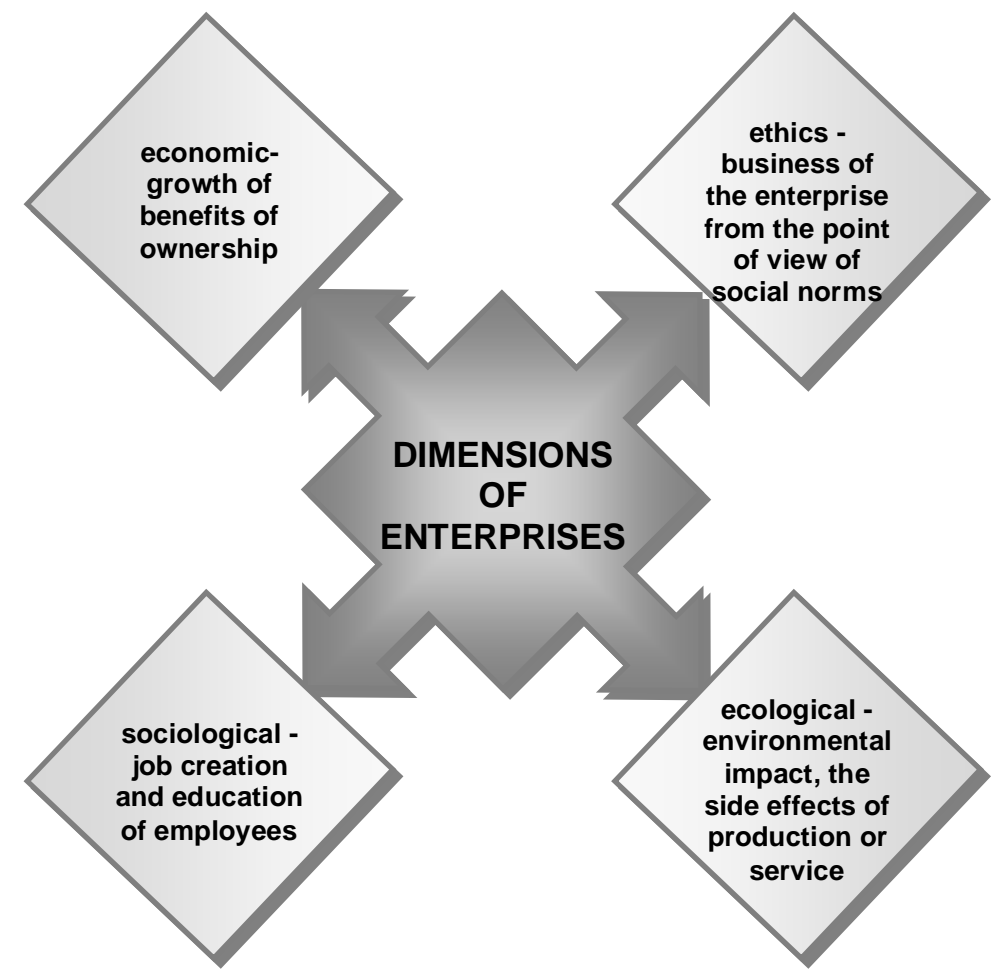

Figure 3. Dimensions of enterprises' activity

Source: Own study based on: Stabryła 2014, pp. 495-504.

Increasing attention is given to the importance of knowledge and its impact on the results of the activity of enterprises. It is thought that the process of knowledge creation and distribution is nothing else but a special kind of services activities Thereby, knowledge enters the market and takes on the form of a commodity. In 
the market economy, this means that knowledge as a commodity that is traded on the market can be sold and purchased. Thus, if knowledge is marketed, then it has value and price, which, in turn, shows that it has many aspects, which has been presented in figure 4.

Since knowledge is marketed, it means that it may be an important source of an enterprise's value. Knowledge as an important element of intangible assets is included both among intangible assets, i.e. in balance sheet, and outside of it. Thus, knowledge can significantly impact the value of an enterprise, and consequently possibility of obtaining more capital than indicated in the balance sheet, and in this aspect it becomes an important factor in development. Knowledge is the most creative source of the development of every enterprise. Since agricultural enterprises include entities whose value is to a large extent created by knowledge, it should be believed that with the increasing importance of knowledge in the economic development the share of knowledge in the value of enterprises will grow as well.

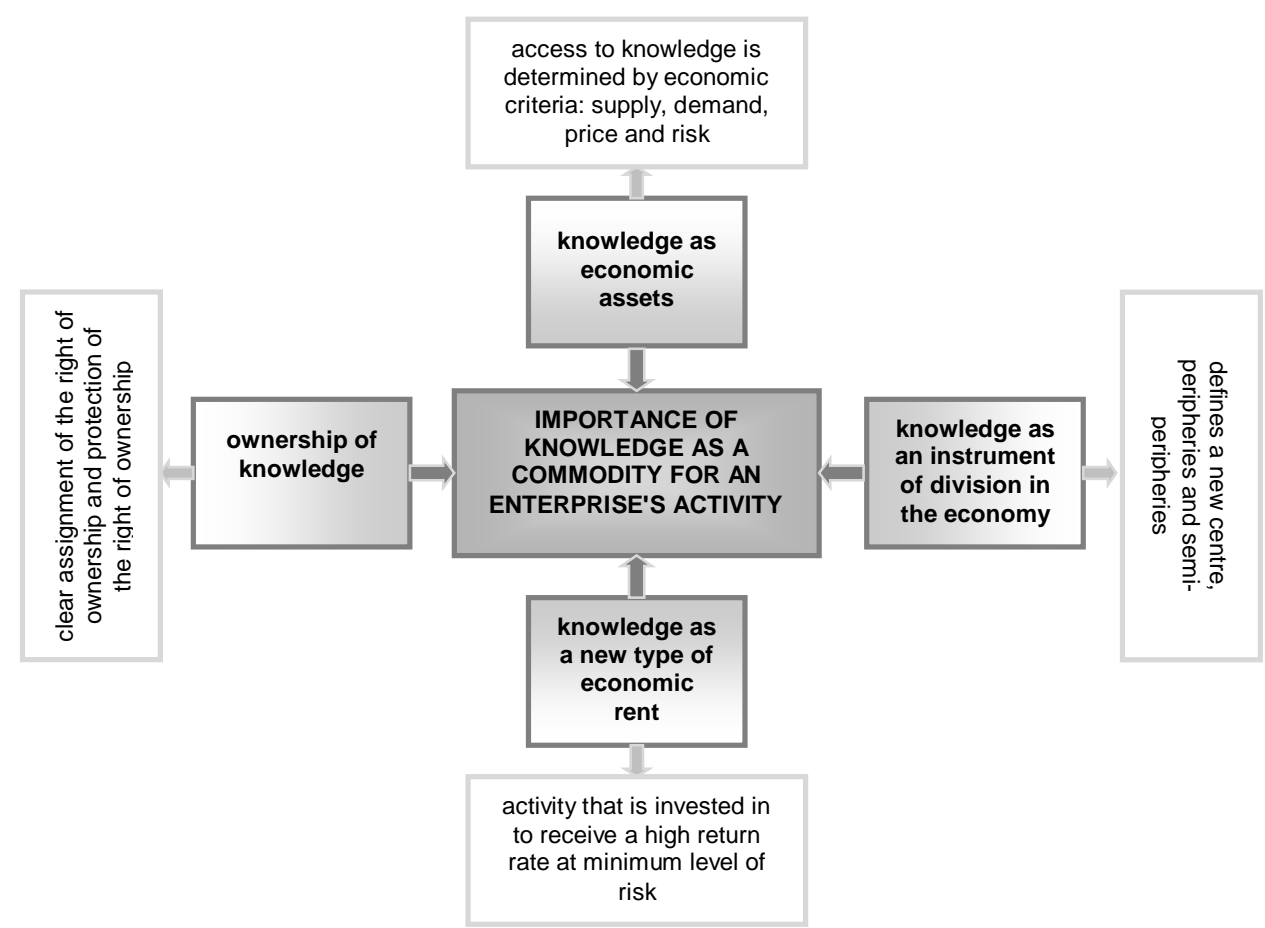

Figure 4. Importance of knowledge as a commodity for the activity of enterprises

Source: Own study based on: Bisaga 2014, pp. 17-25.

\section{Summary}

Based on the discussion in this paper, a thesis can be formulated about comprehensiveness of the issues of management of enterprises. The definition of an enterprise according to which it is an organised system of tangible and intangible assets, singled out in organisational, economic and legal terms, that 
conducts business activity, should be regarded as reductive. Many researchers rightly stress that an enterprise is inscrutable, rich in terms of research problems and constitutes an exciting research subject. Uniqueness of entities, variety of managerial situations, and uniqueness of every man, and thereby a manager, guarantee huge diversity that is interesting from the scientific perspective. These issues will be topical as long as a human will exist with his/her needs, because enterprises will also exist to meet these needs.

\section{References}

1. Bisaga A., Rola sieci dyfuzji wiedzy i informacji $w$ procesie modernizacji gospodarstw rolnych na przykładzie województwa opolskiego, [in:] Journal of Agribusiness and Rural Development, 2014, Vol. 2, No. 32, pp. 17-25.

2. Brzozowska A., Program Rozwoju Obszarów Wiejskich $w$ procesie zarządzania gospodarstwami rolnymi. Wydawnictwo Politechniki Częstochowskiej, Częstochowa, 2013, pp. 44-54.

3. Burmann Ch., Strategische Flexibilität und Strategiewechsel als Determinanten des Unternehmenswertes. Springer-Verlag, Wiesbaden, 2013, pp. 34-37. DOI 10.1007/978-3322-81984-0

4. Czyżewski A., Kryszak L., Sytuacja dochodowa gospodarstw rolniczych w krajach UE-15 $i$ w Polsce $w$ latach 2007-2013 w świetle statystyki FADN, [in:] Zeszyty Naukowe Szkoły Głównej Gospodarstwa Wiejskiego w Warszawie. Problemy Rolnictwa Światowego, 2015, Vol. 15 (XXX), No. 1, pp. 21-32.

5. Domańska A., Serwa D., Koszty kryzysu gospodarczego w Europie na tle innych regionów świata-analiza przekrojowa, [in:] Optimum Studia Ekonomiczne, 2013, Vol. 6, No. 66, pp. 3-19.

6. Feist M., Fuchs D., Agrarpolitik und Ernährungssicherheit im Strudel der Finanzkrise, [in:] Zeitschrift für Außen-und Sicherheitspolitik, 2013, Vol. 6, No. 1, pp. 197-209. DOI 10.1007/s12399-013-0375-7.

7. Figiel S., Kuberska D., Kufel J., Modelowanie rozwoju klastrów rolno-żywnościowych w Polsce. Instytut Ekonomiki Rolnictwa i Gospodarki Żywnościowej - Państwowy Instytut Badawczy, Warszawa, 2014, pp. 23-27.

8. Frank M., Fischer K., Voeste D., BASF: Messbarkeit gemeinsamer Wertschöpfung in der Landwirtschaft, [in:] CSR und Value Chain Management. Springer Berlin Heidelberg, 2014, pp. 217-230. DOI 10.1007/978-3-642-39889-6_8.

9. Haipeter T., Finanzmarktkapitalismus und Arbeit, [in:] Arbeit und Arbeitsregulierung im Finanzmarktkapitalismus, Springer Fachmedien Wiesbaden, 2016, pp. 11-43. DOI 10.1007/978-3-658-10177-0_1.

10. Home R., Jawtusch J., Moschitz H., Das landwirtschaftliche Wissenssystem in der Schweiz: Herausforderungen einer nachhaltigen Entwicklung des ländlichen Raums, [in:] Journal of Socio-Economics in Agriculture (Until 2015: Yearbook of Socioeconomics in Agriculture), 2013, Vol. 6, No. 1, pp. 33-58.

11. Jaki A., Mechanizmy procesu zarządzania wartościa przedsiębiorstwa, [in:] Zeszyty Naukowe/Uniwersytet Ekonomiczny w Krakowie. Seria Specjalna, Monografie, 2012, No. 215, pp. 115-119.

12. Jarka S., Wykorzystanie outsourcingu w przedsiębiorstwach wielkoobszarowych w Wielkopolsce, [in:] Roczniki Ekonomii Rolnictwa i Rozwoju Obszarów Wiejskich, 2013, Vol. 100, No. 2, pp. 88-96.

13. Kagan A., Efektywność i konkurencyjność wielkotowarowych przedsiębiorstw rolnych. Instytut Ekonomiki Rolnictwa i Gospodarki Żywnościowej - Państwowy Instytut Badawczy, Warszawa, 2015, pp. 78-94. 
14. Kleinhanß W., Einkommen versus Faktorentlohnung in der deutschen Landwirtschaft, [in:] Berichte über Landwirtschaft-Zeitschrift für Agrarpolitik und Landwirtschaft. 2015, Vol. 93, No. 2. DOI: http://dx.doi.org/10.12767/buel.v93i2.84.g188.

15. Kozak S., Kryzys finansowy a działalność kredytowa banków spółdzielczych w Polsce, [in:] Roczniki Naukowe Stowarzyszenia Ekonomistów Rolnictwa i Agrobiznesu, 2013, Vol.15, No. 4, pp. 224-230.

16. Matysiak A., Struś M., Paradygmat rozwoju zrównoważonego, [in:] Studia Ekonomiczne, 2015, No. 213, pp. 11-21.

17. Schäfer H. B., Landwirtschaftliche Akkumulationslasten und industrielle Entwicklung: Analyse und Beschreibung entwicklungspolitischer Optionen in dualistischen Wirtschaften. Springer-Verlag, Berlin Heidelberg, 2013, p. 222. DOI 10.1007/978-3-642-68991-8.

18. Stabryła A., Metodyka badania zdolności rozwojowej przedsiębiorstwa, [in:] Prace Naukowe Uniwersytetu Ekonomicznego we Wrocławiu, 2014, No. 366, Zarządzanie strategiczne w teorii i praktyce, pp. 495-504.

19. Wiedemann H., Die Unternehmensentwicklung unter der Lean-Thematik, [in:] Das Unternehmen als dialektisches System. Springer Fachmedien Wiesbaden, 2015, pp. 215-226. DOI 10.1007/978-3-658-07856-0_12

20. Wigier M., Model rozwoju rolnictwa polskiego w świetle efektów realizacji WPR, [in:] Zagadnienia Ekonomiki Rolnej, 2013, Vol. 1, No. 334, pp. 22-41.

21. Winkler P., Grenzen der Flexibilisierung? Bedeutung, Herausforderungen und Konsequenzen der Heterarchie für die interne Kommunikation, [in:] Interne Kommunikation im Wandel. Springer Fachmedien Wiesbaden, 2016, pp. 85-102. DOI 10.1007/978-3-65811022-2_6.

22. Wójcicki Z., Rudeńska B., Systemy rolniczej produkcji ekologicznej i precyzyjnej (informacyjnej), [in:] Problemy Inżynierii Rolniczej, 2015, Vol. 23, No. 2, pp. 5-15.

23. Wulf T., Entwicklung ostdeutscher Unternehmen: Eine Fallstudienanalyse privatisierter Industrieunternehmen. Springer-Verlag, Wiesbaden, 2013. DOI 10.1007/978-3-663-07976-7

\section{ATRYBUTY I WYZNACZNIKI ZARZĄDZANIA PRZEDSIĘBIORSTWEM ROLNYM}

Streszczenie: Celem artykułu jest analiza rozwiązań związanych ze złożoną naturą przedsiębiorstwa oraz próba identyfikacji cech współczesnego przedsiębiorstwa. Przedsiębiorstwo, jako najważniejsze ogniwo w łańcuchu gospodarki narodowej jest złożoną jednostką badawczą. Różnorodność przedsiębiorstw oraz niepowtarzalność praktyk menadżerskich powodują, że zarządzanie przedsiębiorstwem jest analizowane i opisywane przez wiele dyscyplin naukowych.

Slowa kluczowe: zarządzanie przedsiębiorstwem, przedsiębiorstwa rolne, zarządzanie gospodarstwami 